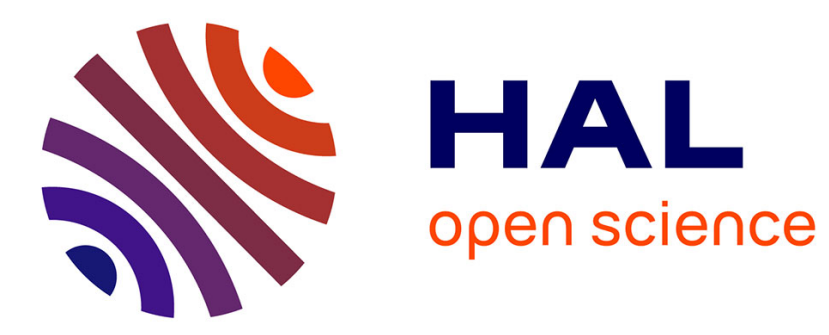

\title{
Methods to design home support for elders
}

Elena Elias, Marc-Eric Bobillier-Chaumon, Michel Vacher

\section{To cite this version:}

Elena Elias, Marc-Eric Bobillier-Chaumon, Michel Vacher. Methods to design home support for elders. HCI International 2018, Jul 2018, Las Vegas, United States. pp.276-289, 10.1007/978-3-319-92037-

5_21. hal-01807679

\section{HAL Id: hal-01807679 \\ https://hal.science/hal-01807679}

Submitted on 28 Aug 2018

HAL is a multi-disciplinary open access archive for the deposit and dissemination of scientific research documents, whether they are published or not. The documents may come from teaching and research institutions in France or abroad, or from public or private research centers.
L'archive ouverte pluridisciplinaire HAL, est destinée au dépôt et à la diffusion de documents scientifiques de niveau recherche, publiés ou non, émanant des établissements d'enseignement et de recherche français ou étrangers, des laboratoires publics ou privés. 


\title{
Methods to design home support for elders
}

\author{
Elena Elias ${ }^{1}$, Marc-Eric Bobillier Chaumon ${ }^{1}$, Michel Vacher ${ }^{2}$ \\ ${ }^{1}$ University of Lyon (Lyon 2) GREPS, Institute of psychology, \\ ${ }^{2}$ University of Grenoble Alpes, CNRS \\ elena.elias@univ-lyon2.fr, chaumon@univ-lyon2.fr, michel.vacher@imag.fr
}

\begin{abstract}
The VOCADOM research project aims to design a new technology (voice control usable at home) to encourage the well-being and autonomy of the elderly with loss of autonomy at home. The user-centered design that we apply must implement methods adapted to these profiles. Which methods are appropriate for this profile to understand their real problems and needs at home and which methods can be mobilised that these people can project themselves into the use of an innovative device?
\end{abstract}

Keywords: Design, SmartHome, Usage study

\section{Introduction}

Population ageing of the industrialised countries in the coming years will sharply increase and by correlation the number of people with loss of their autonomy will considerably increase. This situation will have economic impacts on society and will require additional places within specialised organizations. In the face of this societal context, technological devices are emerging to encourage home support. Among them, home automation systems can be adapted. They make technological services available to users. These services are used in the health and safety areas or to improve the inhabitants well-being. In the case of the elderly, home automation systems can be considered to overcome difficulties with age (loss of memory, physical limitations ...). Our work aims to define more suitable methods for a user-centered design (UCD) when these people are old to encourage the home automation system acceptance. Several issues are targeted within this project, first it is to develop a voice interaction device at home that satisfy needs of users, second it is to develop use prospecting methods for fragile people and finally to develop a new design approach which gathers a set of methods which are applied in situ. This article is organised in three parts. The first part presents the state of knowledge about home support and the proposed solutions to ensure the well-being and autonomy of fragile people. The second part presents the methodology mobilised within the project. Finally, the third part presents first interviews results to the elderly and services to be deployed within Vocadom. 


\section{$2 \quad$ Ageing}

The ageing definition is very controversial. Some authors discuss the old-age as a deterioration of the living conditions due to physical disorders [13] and others as a positive achievement of all abilities [20]. Ageing is still synonymous with fragility. There are several types of fragility. Biological fragility is reflected in physical disorders such as hearing, sight. The proprioception degeneration which causes in the elderly a fear of falling and therefore limits outings [1], which causes a loneliness and a social fragility [18]. Cognitive fragility is recognized by the cognitive decline such as memory and learning disorders [29]. As well as the psychological fragility which implies a loss of identity [28-10] and a reassessment of its role within the society. These fragilities differ from one person to another and can be plural. Formation of these disorders can cause a depression [30] and affect their autonomy and well-being.

\subsection{Loss of autonomy}

The INSEE (National Institute of Statistics and Economic Studies) defines the loss of autonomy of a person as: "a durable state of the person causing disabilities and requiring some help to perform acts of everyday life. The dependence degree of an elderly person depends on disability level and activity restrictions they live, and not directly on their health status [23]." In this way, an elderly person becomes fragile when they need help to carry out an activity of everyday life. Researchers have identified ADL and IADL [24] which are activities of daily living and instrumental activities of daily living that gather all the activities which are carried out in everyday life. Within the CIRDO project [12] ADL were divided into eight dimensions, namely the activities: housewife, nutritional, leisure, rest, mobility, care and hygiene, health and communication. The AGGIR model enables to measure a person's autonomy level. The AGGIR model, Autonomie Gérontologie and Groupe Iso-Ressources "assesses the activities performed or not by the single person and enables to define "ISO resources" groups gathering individuals with levels close to assistance needs to perform everyday life essential acts". This scale is graduated from 6 to 1, 6 represents independent persons for everyday life activities and 1 represents dependent persons with cognitive, physical, social, significant problems requiring a continued assistance. More and more people who lost their autonomy want to live at home [41]. In the face of such situation, there is the question of how to maintain these people at home, through which tools. A discipline then emerged, gerontechnology, to try to satisfy these needs.

\subsection{Gerontechnology}

Gerontechnology is a discipline that aims to improve the daily life of the fragile elderly through technologies in the areas of health and autonomy. This is particularly the remote assistance case which enables the elderly person to press a button during a risk situation and to be automatically linked to a care platform. Also, the development of automatic pill box to deal with the medication forgetting. Despite the birth of several devices, many criticisms have been made because of their using complexity [8], which causes a misuse or non-use [21] and are sometimes considered as a dependence marker [13] and therefore stigmatization [19]. Lie and al [26] suggest that these systems have limits, especially the case of worn devices as remote assistance that users forget to wear them, ambient systems would overcome this problem and do not impose new gestures and habits to integrate in everyday life. Thus, projects in the context of home support are turning to smart home through home automation and more recently the ambient home. 


\section{Smart home vs ambient home}

Smart home is equipped with sensors to analyse activity within the home, such as movements in rooms, the state of openings and closures. It is equipped to facilitate equipment control and to identify anomalies [11]. The concept of Ambient Assisted Living (AAL) has been based and developed on smart home [32], the home is instrumented and equipped with innovative solutions enabling to fragile people such as the elderly to live the longest time at home. AAL solutions have been developed to be accessible and ease to use. Indeed, acceptance by users is essential. Home are thus equipped with micro, cameras and technological tools that measure people physiological data in a constant way. These devices would improve the elderly everyday life by giving them the opportunity to be more autonomous in their daily activities achievement. A study was carried out in the United Kingdom to evaluate the acceptability and the satisfaction of such a device, it is the device SHel (Safe Home Living), it is an ambient remote surveillance system [26-39] for the elderly living alone. This system enables to monitor activities carried out at home and to detect anomalies, when necessary to send an alert to a referent. Results show that one of the conditions for the device use is the trust relationship between the elderly person and his referent. Indeed, the elderly person must agree to share his private life with his referent and therefore must be established so that the device would not be rejected [31]. Lie and al [26] argue that elderly people must be able to control the nature and form of data transmission to their referent. But it requires that the elderly person must have abilities to use the device optimally. The elderly person and the referent must participate in the design of this type of device. Researchers [16] have made a recent comparison of different AAL solutions for the elderly and currently their conclusion is devices are still oriented techno push and do not sufficiently take user needs into account. Moreover, they observe that a solution can answer to a precise situation but cannot be transposable in another situation which does not make it possible to answer to all the problems met by fragile persons.

\section{$4 \quad$ Voice activated personal assistants}

The voice command thus appears to be suitable as an interaction solution for people having difficulties to move or sight problems [34]. Voice activated personal assistants (VAPA) have developed since the 90s and are booming because they have become more efficient thanks to their deep learning and artificial intelligence they have known a significant improvement. The most frequently used VAPA are Apple's Siri, Amazon's Alexa, Microsoft's Cortana and Google Assistant. The voice assistant would be used in priority in a private place so that the information would not be heard [17]. The enthusiasm of these devices comes from an anthropomorphic need [33], indeed, the voice assistant would be perceived as a companion because words are increasingly recognized. But this can cause confusion among users who perceive these devices as systems enable to understand human language. In reality their abilities are limited, indeed, these devices have their own language, the user must comply. These devices emerge even within home in particular with Amazon Echo in 2014, Google Home in 2016 in the United States, and this is the beginning Google Home has just appeared in France and other operators will develop. One of the limits of these devices is that data is released and collected outside the home. 


\section{Approach}

\subsection{Vocadom project}

The Vocadom project has the purpose of forcing knocks presented above. From an acceptability point of view, the device must satisfy the real needs of the elderly and adapt to their functional limits. From a technical point of view the device must be able to recognize the elderly voices and build an interaction syntax so that it is available from this profile. Also, the Vocadom device focuses on providing a "capacitant" device [4] to supplement encountered problems.

\subsection{Design}

We want to combine two design approaches. Namely, the user-centered design (UCD) approach that responds ISO 9241-11 and ISO 9241-210 (before ISO 13407) standards, emerges from ergonomics of human-system interfaces (HSI). This approach aims to understand the use context by involving end-users in the design process to design a device respecting the usability criteria. It mobilises various and rigorous methods of data collection. The user-centered design approach enables to direct design choices according to user needs with iterative loops. Applying this approach for the Vocadom project seems essential to us, indeed, it enables to have a user's feedback at each decisive phase of the design cycle to ensure that the device satisfies needs and is adapted to users and when necessary, to be able to readjust design choices. But as LespinetNajib and al. [25] noted, the UCD approach has its limits. Indeed, "the resulting tools and / or services too often correspond to expectations and needs of the majority (80\%) of the population and hence can set people with very specific profiles aside such as people in fragility situation and / or with a disability". Similarly, these authors insist on the fact that developing a device for a particular profile such as blinds excludes a population with multiple disabilities. They advocate a so-called universal design. The so-called universal design comes from architecture. Mace [27] defines as a design "to create, develop and market products, services, systems or current environments that are accessible and usable by the widest range of users". In particular, researchers [37] have created seven principles applied to universal design. Each principle has its own guidelines. The first must take all users into account without stigmatizing them. The second involves adapting to individual abilities in other words that it is flexible. The third indicates that the device must be understandable by all, independently of the user experience. The fourth is to make the information accessible in a multimodal way and to be able to use different supports. The fifth advocates minimizing error risks and having security features. The sixth indicates that the device should be used efficiently with low cognitive and physical load. And finally, the last principle is that the device must take the space and size into account so that it is suitable for all, if the person is sitting or standing. Lespinet-Najib and al. [25] argue that universal design should not be considered as utopia but as a societal issue that could also be applied to living labs. For these authors, coupling these two types of design would enable on the one hand to compensate for user's functional limitations by developing technical assistances adapted to the use, and on the other hand to take everyone's diversity into account so that the developed device is accessible for everyone. We are in the context of the Vocadom project, indeed the elderly have interindividual variations that must be taken into consideration, for example an elderly person may be hearing and visually impaired. So, we want to be part of these two design approaches, we want to develop a device dedicated to the elderly by taking their multiple fragilities into account but one of the conditions is that the person is able to use this system and this person has not a serious cognitive pathology. 




Fig. 1. Progress of project

As presented above, we carry out a user-centered and universal design approach that involves iterative loops with future users. First, in a comprehensive approach we carry out a study of the socio-domestic activities in ecological situation. It enables to make an analysis of needs and socio-domestic activities taking the ecosystem of the person into account. Following these initial results, problematic situations are identified in which the device could be useful. Interaction modes and functionalities will be co-built with the elderly and family and professional caregivers in a second time. Finally, we will evaluate the acceptation and usability of the device developed with the target population and caregivers in simulated environments and real situations.

\subsection{Uses prospective}

According to Brangier [7] during the "prospecting: ergonomics seeks to detect current needs, anticipate future needs and understand the technological, social, cultural and economic factors that lead to the creation of new products and services. Its innovative potential is huge". In ergonomic psychology, the intention and uses maintenance are particularly measured by social acceptability questionnaires such as the UTAUT 2 model [40] which enables to forecast attitudes (favourable or not) towards technologies on different socio-cognitive indicators (behavioural control, subjective norms, behavioural intention ...). However, this type of methods is not suitable for elderly because of a misunderstanding of measurement scales or a social desirability bias [36]. Moreover, it seems difficult for these elderly to project themselves into the probable future use of such an innovative technology, while they have no experience with equivalent systems. Finally, what has been evaluated in terms of acceptability at a one point and under certain conditions (of experimentation, training, awareness) may no longer have value once the device is deployed and used in its real use environment: constraints, circumstances of life and the psychosocial context can give another meaning and induce a report / special needs with the technology. In other words, social acceptability cannot priori guarantee by itself the final technologies adoption [5]. This is why in our project, we use a methodological triangulation approach and different innovative methods that can be used with the elderly and which are part of the located acceptance approach [5], which comprehends, in effective context of life, the actual activity and use of the technical object. Use and practice are then to be considered as determinant of acceptance. The idea is not so much that home stakeholders have a favourable representation of the technical object, but that these technologies have indeed a favourable effect on the individual and collective activity of these people [3]. We apply the activity simulation method used in the organisational simulation approach [2] in order to co-build uses scenarios with future users by taking the domestic organisation and future uses into account. It is implemented with tangible material such as models and figures. With caregivers, we use the method of participative design sessions that enables through scenarios, modelling, to project in the use of the device 
and to identify the desired features and interaction modes. Finally, we will evaluate the device developed in simulated environments by means of the $\mathrm{Oz}$ Wizard to evaluate its acceptance and usability with the target population.

\subsection{Ethnographic activity approach}

As we have seen above, it is essential to take real needs of the elderly into account. This is why we carry out an ethnographic approach that enables to know the existing uses within their housing. It is a comprehensive approach that enables to apprehend the life practices, mobilised resources and daily constraints of the person in order to identify and evaluate on the one hand, the different activities (in terms of nature, but also of cost, difficulty, required organisation efficiency - individual and collective, etc.) and define, on the other hand, the meaning that these tasks hold for the person (what do they represent for the person and for his different life systems: personal, social, domestic, family...). This ethnographic and anthropocentric approach is indispensable in a usercentered design approach so that the device not only responds to real needs of the target population, but also enables the activity development, giving the power to act and action abilities to these fragile public [6]. We are also interested in people who regularly intervene at home to the extent that these will also be impacted by the device implementation and they can become prescribers or proscribers of the device use. Caregivers are called upon as soon as the needs are studied. In addition to analysing their activity at home (what they do at home, alone / with the elderly, the way activities are organized, co-build with seniors ...), focus groups are also put in place so that caregivers can share their experiences and opinions for home support. This technique enables us to identify the roles and performed tasks with people, and to collectively consider the role that the technical artefact can play and must fit into the activity system of the house. In this article, we present a part of the results from this needs study.

\section{$6 \quad$ First results}

We conducted interviews and observations with the elderly and identified problems encountered at home according to the ADL proposed in the CIRDO project.

Table 1. Respondents profile

\begin{tabular}{|c|c|c|}
\hline & $\mathbf{N b}$ & $\%$ \\
\hline \multicolumn{3}{|c|}{ GENDER } \\
\hline Male & 5 & $12.8 \%$ \\
\hline Female & 34 & $87.2 \%$ \\
\hline \multicolumn{3}{|c|}{ GIR } \\
\hline GIR 1 & 0 & $0 \%$ \\
\hline GIR 2 & 3 & $7.7 \%$ \\
\hline GIR 3 & 8 & $20.5 \%$ \\
\hline GIR 4 & 8 & $20.5 \%$ \\
\hline GIR 5 & 7 & $17.9 \%$ \\
\hline GIR 6 & 13 & $33.3 \%$ \\
\hline \multicolumn{3}{|c|}{ AGE } \\
\hline $70-79$ years & 7 & $18 \%$ \\
\hline $80-89$ years & 19 & $48.7 \%$ \\
\hline $90-99$ years & 13 & $33.3 \%$ \\
\hline \multicolumn{3}{|c|}{ HOME } \\
\hline Flat & 21 & $53.8 \%$ \\
\hline House & 12 & $30.8 \%$ \\
\hline Storey house & 6 & $15.4 \%$ \\
\hline \multicolumn{3}{|c|}{ MARITAL SATUTS } \\
\hline Widow(er) & 24 & $61.5 \%$ \\
\hline Married & 12 & $30.8 \%$ \\
\hline Divorced & 2 & $5.1 \%$ \\
\hline
\end{tabular}

39 elderly people was interviewed through semi-structured interviews. All the people had functional limitations at different levels and for some elderly people they were multiple. 


\subsection{Personas}

In order to synthesize results we created personas. A persona is a fictional character who represents the user profile. It represents all respondents who match the profile. It is used as a guideline during the design. We thus identified 3 personas representing our target profiles with their characteristics, their context of life, their problems encountered at home as well as their technologies uses.
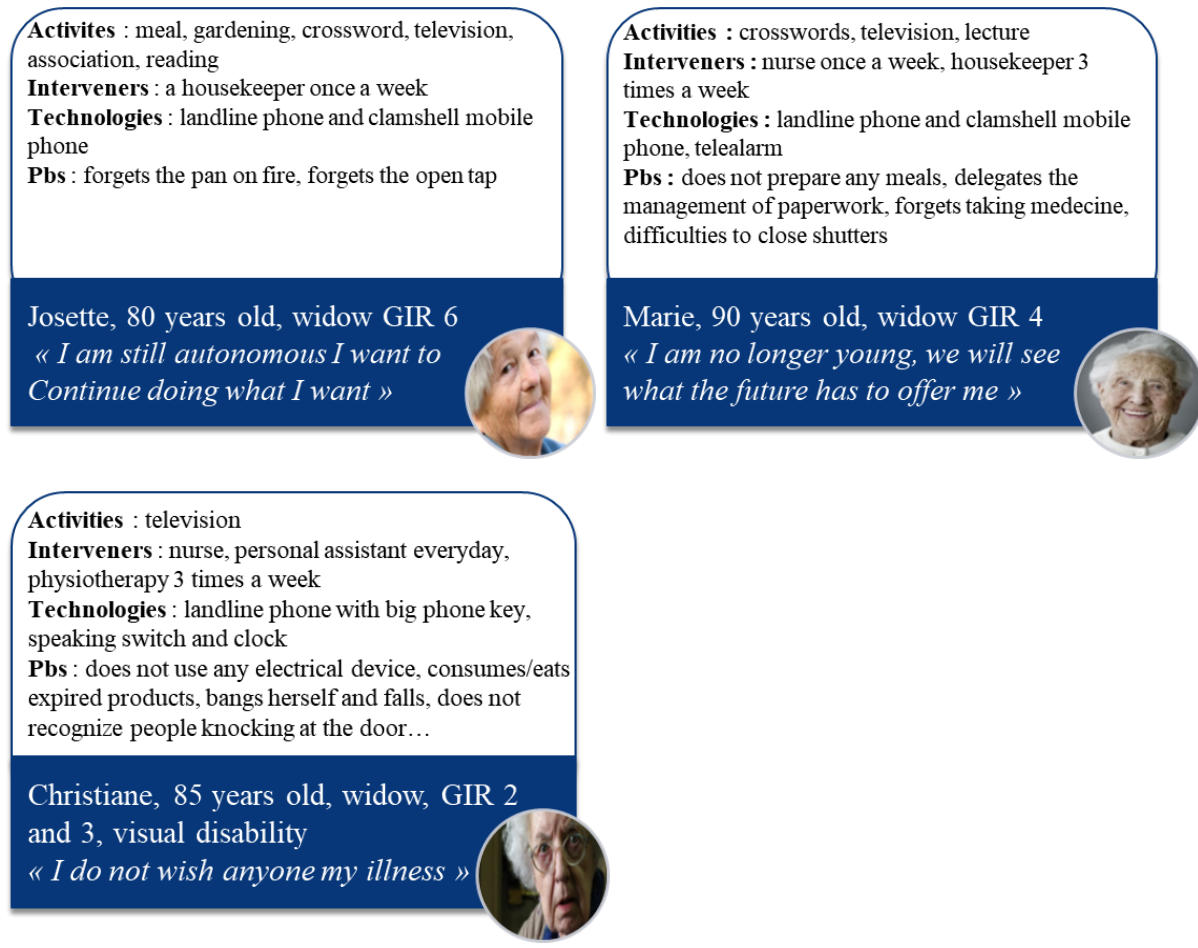

Fig. 2. Elderly personas

These personas will serve as a basis for the design cycle and especially for the realisation of working sessions, focus group or creative sessions.

\subsection{Problems encountered according to ADL}

In order that the Vocadom device overcomes the difficulties encountered at home, it was relevant to classify them by ADL. Within the household sphere, the elderly people encounter difficulties in the housing maintenance, laundry, storage and clothing. We present here a visualization of the problems encountered for the household sphere: 


\section{Household sphere}

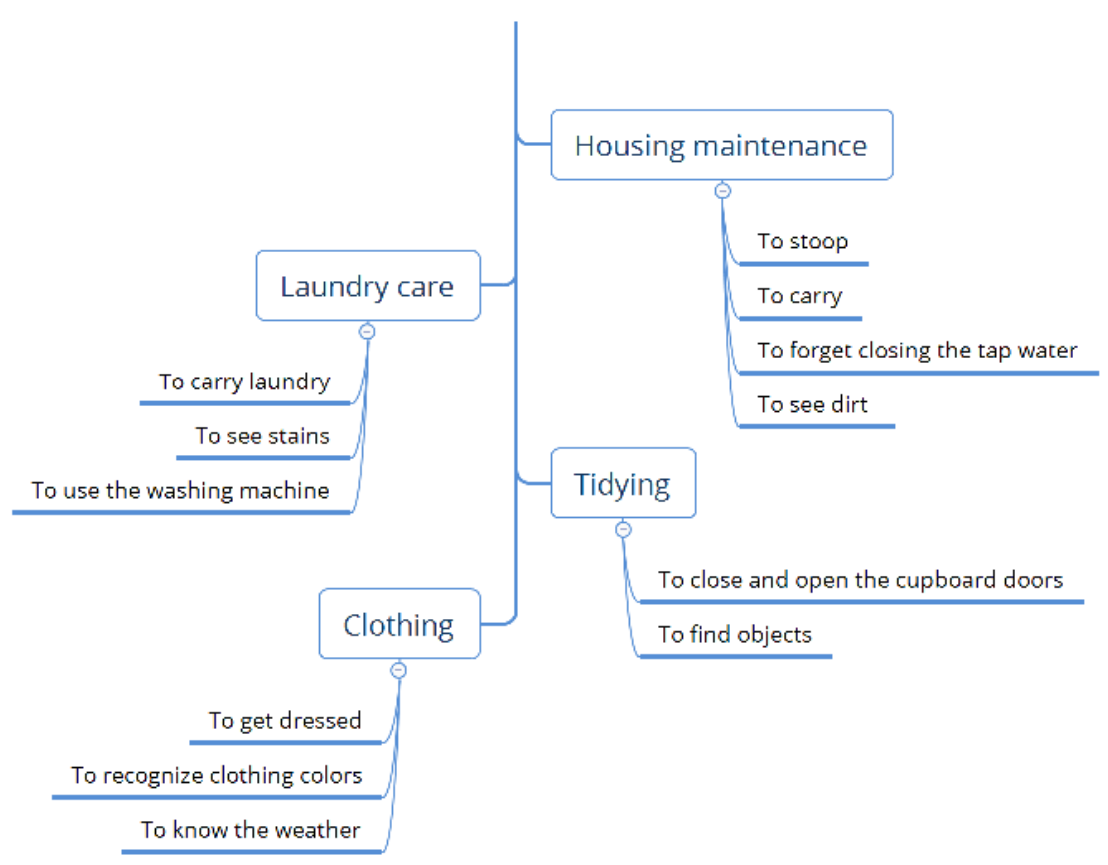

Fig. 3. Problems within the household sphere by the elderly

The food sphere is marked by the difficulties concerning the preparation of meals and to do shopping. The leisure sphere identifies the problems related to the use of technological equipment that is considered complex or not adapted to their uses such as television, radio or even the computer (among our panel only 6 people have one). The communication sphere is also marked by difficulties in using the mobile phone, people have also difficulties to recognize a person who knocks at the door because of hearing or sight problems. The management of their appointments and administrative papers are tedious due to memory problems, understanding and legibility of documents. Within the health sphere it is the forgetting either taking the bad medicine due to a memory failure or sight disabilities which do not enable to recognize the good medicine. The resting sphere is marked by falls when people get up during the night to use the toilet. Which is similar with the falls problems listed within the mobility sphere and which cause the fall of some people to stay at home. In the face of these problems, people usually call in a third person, generally a relative or home help, who partially or totally perform the difficult task. The caregivers are thus very requested. The Vocadom device aims to support the elderly in these difficulties, so we had to identify these problems to define situations that the device could help.

\subsection{Services offered with Vodacom}

To do this, we conducted work sessions with project teams in informatics and linguistics. From storyboards presenting problematic situations encountered by the elderly we were able to determine services to develop within the device. These storyboards enabled to share real situations lived by the people and to enable teams to project themselves in possible services by taking the technical constraints. 


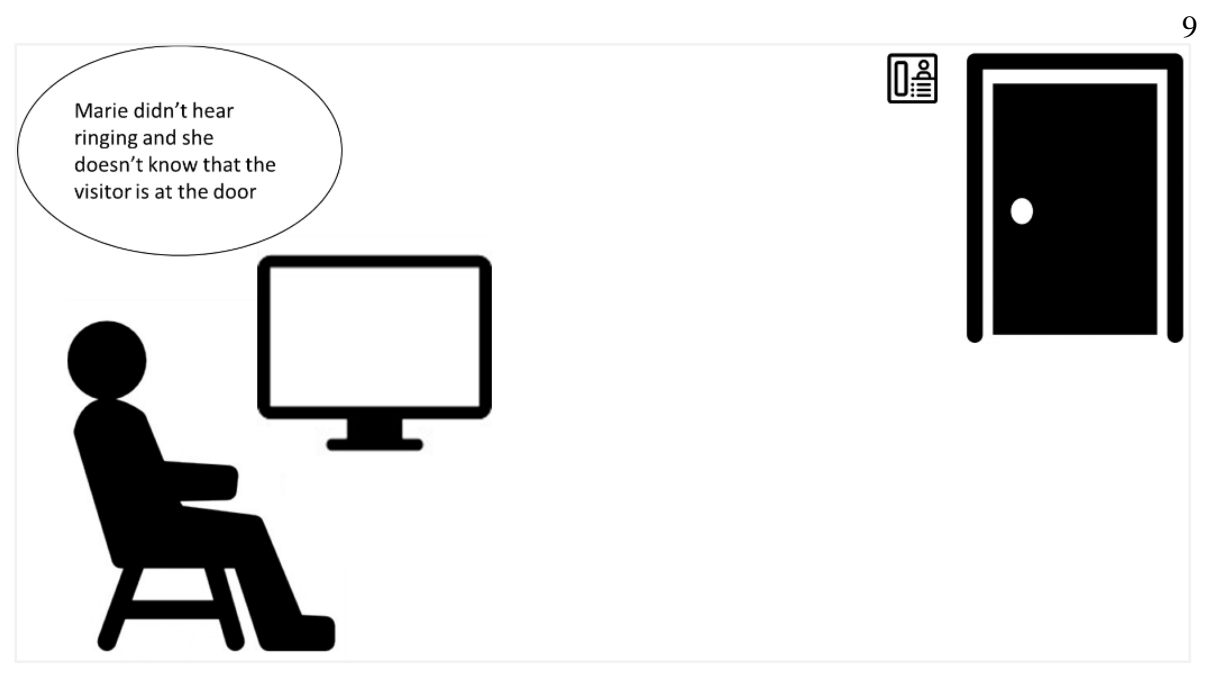

Fig. 4. Storyboard don't hear the belle ring

We have defined 7 major services. Thanks to the Vocadom device, the elderly person will be able to interact with his environment to control his home automation system and his household appliances. The environment can also inform himself during anomalies and trigger alerts if necessary. The day organisation of an elderly person is structuring so we want to offer consultation appointments of the person. It will also be possible to call in a hands-free kit. Vocadom will be able to support the person during the preparation of meals and help him to locate his lost items.

\subsection{Possible limits}

We see that the elderly are poorly equipped with technological items, they essentially have the mobile phone. This confirms the literature studies [8] that suggest that the elderly people do not feel concerned by technologies because of a generational effect and their functional limitations. This statement is still current and raises the question of the future acceptation of the VOCADOM device. In the same way, the elderly are committed to activities that they can still carry out independently, the shutters opening and closing can be considered as tedious tasks for as much however our elders wish to keep this task which gives them an autonomy feeling and spend their day [15]. Here the VOCADOM device would enable people to control their shutters through voice control, but this could be rejected by users who wish to keep this activity.

\section{Conclusion}

This article enabled to determine the positioning of the Vocadom project within the literature and the challenges to rise. Thus, the Vocadom project aims to develop a voice control solution enabling the elderly to be more autonomous at home by moving into a "capacitant" home. This device will enable people to be supported during the activities realisation. An ethnographic study was conducted with the target population to identify problems encountered at home and to target situations in which Vocadom could intervene. We have been able to identify services that the device could act, then we must mobilize innovative methods including simulation activities to validate defined services for the elderly.

\section{Acknowledgement}

The Vocadom project is funded by the French National Research Agency (ANR) and is conducted by the collaboration of these laboratories: GETALP of the University of Grenoble-Alpes, GRePS of the University of Lyon and the INRIA of Nancy. URL: https://vocadom.imag.fr/ 


\section{Appendix}

Table 2. Detailed profile of respondents

\begin{tabular}{|c|c|c|c|c|c|c|c|}
\hline Subject & Age & Gender & GIR & Marital status & Leave & Accommodation & Geographic location \\
\hline 1 & 92 & $\mathrm{~F}$ & 6 & Widow(er) & Single & Flat & Urban \\
\hline 2 & 93 & $\mathrm{~F}$ & 4 & Widow(er) & Single & House & Peri-urban \\
\hline 3 & 85 & M & 3 & Married & In a couple & Flat & Peri-urban \\
\hline 4 & 77 & F & 2 & Married & In a couple & Flat & Peri-urban \\
\hline 5 & 88 & M & 3 & Married & In a couple & House & Rural \\
\hline 6 & 88 & $\mathrm{~F}$ & 2 & Married & In a couple & Flat & Peri-urban \\
\hline 7 & 95 & F & 3 & Widow(er) & Single & House & Peri-urban \\
\hline 8 & 90 & F & 4 & Divorced & Single & Flat & Peri-urban \\
\hline 9 & 93 & $\mathrm{~F}$ & 3 & Married & In a couple & Flat & Peri-urban \\
\hline 10 & 89 & $\mathrm{~F}$ & 6 & Widow(er) & Single & House & Rural \\
\hline 11 & 88 & F & 4 & Widow(er) & Single & House & Rural \\
\hline 12 & 90 & F & 5 & Widow(er) & Single & House & Rural \\
\hline 13 & 85 & $\mathrm{~F}$ & 6 & Widow(er) & Single & Flat & Rural \\
\hline 14 & 79 & $\mathrm{~F}$ & 6 & Widow(er) & Single & House & Rural \\
\hline 15 & 85 & F & 6 & Married & Single & Storey house & Rural \\
\hline 16 & 72 & $\mathrm{~F}$ & 5 & Divorced & Single & Flat & Rural \\
\hline 17 & 92 & $\mathrm{~F}$ & 6 & Widow(er) & Single & House & Peri-urban \\
\hline 18 & 89 & $\mathrm{~F}$ & 4 & Widow(er) & Single & Storey house & Peri-urban \\
\hline 19 & 81 & $\mathrm{~F}$ & 6 & Married & Single & Storey house & Peri-urban \\
\hline 20 & 97 & $\mathrm{~F}$ & 5 & Widow(er) & Single & House & Peri-urban \\
\hline 21 & 83 & $\mathrm{~F}$ & 4 & Widow(er) & Single & Storey house & Peri-urban \\
\hline 22 & 85 & $\mathrm{~F}$ & 4 & Single & Single & Flat & Urban \\
\hline 23 & 77 & $\mathrm{~F}$ & 6 & Widow(er) & Single & Storey house & Peri-urban \\
\hline 24 & 85 & F & 4 & Widow(er) & Single & House & Urban \\
\hline 25 & 81 & F & 5 & Widow(er) & Single & Flat & Urban \\
\hline 26 & 76 & $\mathrm{~F}$ & 6 & Widow(er) & Single & Flat & Urban \\
\hline 27 & 90 & M & 5 & Married & In a couple & Flat & Peri-urban \\
\hline 28 & 87 & $\mathrm{~F}$ & 6 & Married & In a couple & House & Rural \\
\hline 29 & 85 & $\mathrm{~F}$ & 6 & Married & In a couple & Flat & Peri-urban \\
\hline 30 & 90 & $\mathrm{M}$ & 6 & Married & In a couple & Flat & Peri-urban \\
\hline 31 & 80 & M & 5 & Married & In a couple & Flat & Peri-urban \\
\hline 32 & 86 & $\mathrm{~F}$ & 3 & Widow(er) & Single & Flat & Urban \\
\hline 33 & 94 & F & 3 & Widow(er) & Single & Storey house & Rural \\
\hline 34 & 89 & $\mathrm{~F}$ & 6 & Widow(er) & Single & Flat & Rural \\
\hline 35 & 74 & $\mathrm{~F}$ & 5 & Widow(er) & Single & Flat & Peri-urban \\
\hline 36 & 80 & $\mathrm{~F}$ & 4 & Widow(er) & Single & House & Rural \\
\hline 37 & 94 & $\mathrm{~F}$ & 3 & Widow(er) & Single & Flat & Rural \\
\hline 38 & 73 & $\mathrm{~F}$ & 2 & Widow(er) & Single & Flat & Peri-urban \\
\hline 39 & 92 & $\mathrm{~F}$ & 3 & Widow(er) & Single & Flat & Urban \\
\hline
\end{tabular}

\section{References}

1. Ballinger, C., \& Payne, S. (2002). The construction of the risk of falling among and by older people. Ageing \& Society, 22(3), 305-324.

2. Barcellini,F., Van Belleghem, L., and Daniellou, F., 2013. Les projets de conception comme opportunité de développement des activités. In Ergonomie constructive. Presses universitaires de France, 191-206.

3. Bobillier-Chaumon, M-E. (2013). Conditions d'usage et facteurs d'acceptation des technologies dans l'activité: questions et perspectives pour la psychologie du travail (Habilitation à Diriger la Recherche). Université Pierre-Mendès-France, Grenoble.

4. Bobillier-Chaumon, M-E. et al. (2014). Concevoir une technologie ambiante pour le maintien à domicile : une démarche prospective par la prise en compte des systèmes d'activité. Le travail humain, 77(1), 39-62.

5. Bobillier Chaumon, M-E., (2016). L'acceptation située des technologies dans et par l'activité : Premiers étayages pour une clinique de l'usage. Psychologie du Travail et des Organisations 22, 1 (2016), 4-21.

6. Bobillier Chaumon, M-E, Clot, Y. (2016). Clinique de l'usage : Les artefacts technologiques comme développement de l'activité. Synthèse Introductive au dossier. Activités 13, 2 (2016).

7. Brangier, Robert, J-M. 2012. L'innovation par l'ergonomie : éléments d'ergonomie prospective. Innovation, connaissances et société : vers une société de l'innovation (2012), 59-82.

8. Caradec, V. (1999). Vieillissement et usage des technologies. Une perspective identitaire et 
relationnelle. Réseaux, 17(96), 45-95. https://doi.org/10.3406/reso.1999.1059

9. Caradec, V. (2003). Comportements culturels de la population âgée. Empan, 52(4), 54. https://doi.org/10.3917/empa.052.0054

10. Caradec, V. (2007). L'épreuve du grand âge. Retraite et société, 52(3), 11-37. Récupéré du site sur http://www.cairn.info/revue-retraite-et-societe-2007-3-page-11

11. Chen, L., Nugent C. (2009) Ontology-based activity recognition in intelligent pervasive environments. International Journal of Web

12. CIRDO ( « Compagnon Intelligent Réagissant au Doigt et à l'Oeil »- financements ANR et CNSA) réunit plusieurs partenaires industriels et scientifiques issus de différentes disciplines : Laboratoires de traitement de l'image et du langage (GETALP, LIRIS) et laboratoire en psychologie de la santé, ergonomique et du travail (GRePS). Partenaires industriels TECHNOSENS, CATEL, IRSAP et FSI.

13. Clement, S., Rolland, C. et Thoer-Fabre, C. (2005). Usages, normes, autonomie : analyse critique de la bibliographie concernant le vieillissement de la population. https://f.hypotheses.org/wp-content/blogs.dir/2438/files/2016/02/Rapport-Usages-NormesAutonomie-1

14. Davin, B., Paraponaris, A. et Verger, P. (2008). Entraide formelle et informelle: Quelle prise en charge pour les personnes âgées dépendantes à domicile ?. Gérontologie et société, 127(4), 49-65. doi:10.3917/gs.127.0049.

15. Demeure, A., Caffiau, S., Elias, E and Camille Roux. (2015). Building and using home automation systems : a field study. In Internation Symposium on End User Development. Springer, $125-140$.

16. Desai A. and Jhaveri. R (2017) A Review on Applications of Ambient Assisted Living. International Journal of Computer Applications 176(8):1-7

17. Easwara Moorthy, A., \& Vu, K.-P. L. (2015). Privacy Concerns for Use of Voice Activated Personal Assistant in the Public Space. International Journal of Human-Computer Interaction, 31(4), 307-335. https://doi.org/10.1080/10447318.2014.986642

18. Freund, A. M., Baltes, P. B. (2000). The orchestration of selection, optimization and compensation: An action-theoretical conceptualization of a theory of developmental regulation. In W. J. Perrig \& A. Grob (Eds.), Control of human behavior, mental processes, and consciousness: Essays in honor of the 60th birthday of August Flammer (pp. 35-58). Mahwah, NJ: Lawrence Erlbaum

19. Goffman E. (1977) Les stigmates : Les usages sociaux des handicaps Paris : Ed. de Minuit.

20. Guérette, M-J., Caradec, V., Bergman, H., Joanette, Y et Blanchard, F. (2006). La vieillesse, c'est le déclin, on n'y peut rien. Santé, Société et Solidarité, (1), 23-31.

21. Hem, C. (2015). Le téléphone, un artefact témoin du bien-être des personnes-âgées (thèse de doctorat, Université de Grenoble).

22. Information Systems,5(4):410-430.

23. INSEE. (2014). Personnes âgées dépendantes. Tableaux de l'Économie Française. https://www.insee.fr/fr/statistiques/1288358?sommaire $=1288404$

24. Lawton, M.P., \& Brody, E.M. (1969). Assessment of older people: Self-maintaining and instrumental activities of daily living. The Gerontologist, 9 (3), 179-186.

25. Lespinet-Najib, V., Roche, A., \& Chibaudel, Q. (2017). Santé et handicap: d'une conception centrée « utilisateur » à la conception universelle. In Annales des Mines-Réalités industrielles (p. 25-27). FFE.

26. Lie, M., \& Brittain, K. (2016). Technologie et confiance. Retraite et société, (3), 47-72.

27. Mace R., Definitions : accessible, adaptable et universal design, The center for universal Design, Raleigh, 1990

28. Michel, C., Bobillier-Chaumon, M-E. et Tarpin-Bernard, F. (2009). Fracture numérique chez les seniors du 4ème âge. Observation d'une acculturation technique. Les Cahiers du numériques, 5(1), 147-168.

29. Moget, C., Bonnardel, N., \& Galy-Marie, E. (2014). Ergonomie prospective et âge : proposition de méthodes nouvelles pour la conception d'un système de maintien à domicile. Le travail humain, 77(3), 231. https://doi.org/10.3917/th.773.0231

30. Monfort, J. (2001). Spécificités psychologiques des personnes très âgées. Gérontologie et société, 98(3), 159-187. doi:10.3917/gs.098.0159

31. Mortenson W.B, Sixsmith A., Beringer R., (2015) « The Power(s) of Observation : theorical Perspectives on Surveillance Technologies and Older People « Ageing \& Society, vol. 35, $\mathrm{n}^{\circ} 3$, p.512-530

32. Nehmer, J., Becker, M., Karshmer, A., Lamm, R., (2006) Living assistance systems: an ambient intelligence approach. Proceedings of the 28th international conference on Software engineering. pp. $43-50$

33. Poirier, F. (2017). Quelle modalité pour l'interaction avec les petits appareils mobiles et 
vestimentaires: texte ou vocal? Comment choisir entre clavier et assistant personnel? In 29ème conférence francophone sur l'Interaction Homme-Machine (p. A-67).

34. Portet F., Vacher M., Golanski C., Roux C., Meillon B. (2013) Design and evaluation of a smart home voice interface for the elderly: acceptability and objection aspects, Personal and Ubiquitous Computing, 17(1): 127-144, 2013.

35. Ramos C. (2007) Ambient Intelligence - A State of the Art from Artificial Intelligence Perspective. In: Neves J., Santos M.F., Machado J.M. (eds) Progress in Artificial Intelligence. EPIA 2007. Lecture Notes in Computer Science, vol 4874. Springer, Berlin, Heidelberg

36. Reerink-Boulanger,J., (2012). Services technologiques intégrés dans l'habitat des personnes âgées : examen des déterminants individuels, sociaux et organisationnels de leur acceptabilité. Ph.D. Dissertation. Université Rennes 2.

37. The Center for Universal Design. (1997). The Principles of Universal Design (Version 2.0). Raleigh, NC: NC State University, Author.

38. Venkatesh,V., Thong, J., and Xu, X., 2012. Consumer Acceptance and Use of Information Technology : Extending the Unified Theory of Acceptance and Use of Technology. (2012).

39. Vines, J., Lindsay, S., Pritchard, G. W., Lie, M., Greathead, D., Olivier, P., \& Brittain, K. (2013). Making family care work: dependence, privacy and remote home monitoring telecare systems (p. 607). ACM Press. https://doi.org/10.1145/2493432.2493469

40. Viswanath Venkatesh, James Thong, and Xin Xu. 2012. Consumer Acceptance and Use of Information Technology : Extending the Unified Theory of Acceptance and Use of Technology. (2012).

41. Wiles, J. L., Leibing, A., Guberman, N., Reeve, J., \& Allen, R. E. S. (2012). The Meaning of « Aging in Place » to Older People. The Gerontologist, 52(3), 357-366. https://doi.org/10.1093/geront/gnr098 